ӘОЖ 72.02. 035: (574-21)

https://doi.org/10.51488/1680-080X/2021.3-03

МРНТИ 67.07:03

\title{
К.К. Арынов*
}

Л.Н.Гумилев атындағы Еуразия ұлттық университеті, Нұр-Сұлтан, Қазақстан

Автор туралы ақпарат:

Арынов Қалдыбай Қанайұлы - архитектура докторы, Л. Н. Гумилёв атындағы Еуразия ұлттық университетінің профессоры, Нұр-Сұлтан, Қазақстан

https://orcid.org/0000-0003-0799-8574, email: kalan1960@mail.ru

\section{СӘУЛЕТТІК-ТАРИХИ ҚҰНДЫЛЫҚ - ХАЛЫҚ ҚАЗЫНАСЫ}

Андатпа. Мақ̧алада Семей қ̧аласы, Абай көшесі, 94 үй мекенжайында орналасқ̧ан сәулеттік-тарихи маңызы бар Қазақ инновациялық гуманитарлық-заң университетінің оқу zимаратын құайта құалпына келтіру жұмытарының кезеңзік нәтижелері тураль және басқ̧а да құнды сәулеттік ескерткіштердің қазіргі жавдайы мен оның болашақ ұрпаққтың алдындавы рухани маңыздылывы туралы мәселелер баяндалады.

Түйін сөздер: сәулеттік-тарихи маңъызы бар ескерткіштер, қ̧айта қ̧алпына келтіру, күрделі жөндеу, құасбет, орыс классищизмі стилінде тұрвызылван вимарат.

Кіріспе. Мақаланың негізгі желісі Абай көшесі, 94 үй мекенжайында орналасқан сәулеттік-тарихи маңызы бар және өзінің мәдени-рухани құндылықтарымен ерекшеленетін университеттің оқу ғимараты турасында болғалы тұр.

Аталмыш ғимарат тек қана Семей қаласында емес, сонымен бірге Республика деңгейінде өзінің бірегейлігімен, тарихи құндылығымен ерекшеленеді (1-сурет).

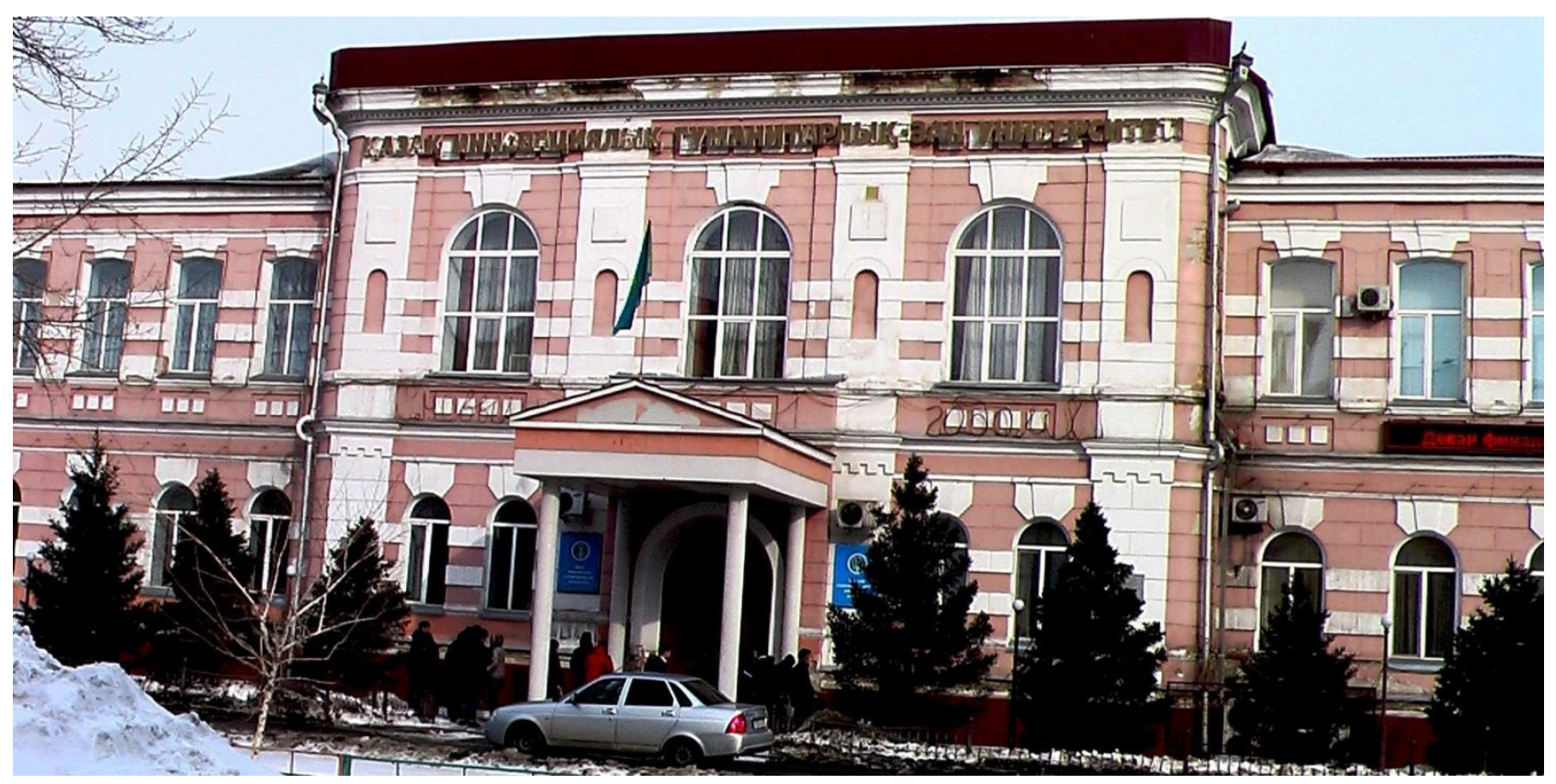

1-сурет - Қазақ инновациялық гуманитарлық-заң университеті ғимаратының қайта қалпына келтіргенге дейінгі көрінісі 
Материалдар және әдістер. Ғимарат 1872 жылы тұрғызылған, мемлекет қарамағындағы тарихи-сәулет ескерткіші болып табылады. Ғимарат бұрын 18941919 жылдары Қазақ ССР педагогикалық институтының оқу корпусы (бұрынғы ерлер гимназиясы), 1919-1934 жылдары 11-ші ақ гвардияшылардың Сібір округтік штабы. 1934 жылдан бері түрлі оқу орындарына қызмет атқарып келді, ал Қазіргі кезде Қазақ инновациялық гуманитарлық-заң университетінің оқу корпусы болып табылады. Байқап отырғандай, аталмыш ғимарат қойнауында талай тылсым тарихтың сан-қилы тағдырларын бүркемелеп жатыр $[1,3,5]$.

Ғимараттың жалпы сұлбасы (схемасы) П әріпі тәріздес орналасқан орыс классикалық стилде орындалған, қызғылт (розовый) және ақ түстерден құралып әрленген 2-қабатты үй. Абай көшесі жағында орналасқан негізгі қасбеті ұзындығы 40000 мм (40 м) (1-сурет). Ғимараттың сыртқы беті дәстүрлі әк араласқан құмсылақпен (традиционный известково-песчанный раствор) сыланған. Ғимарат үш деңгейден тұрады - негізгі 1 және 2-қабаттар және астыңғы қабаты. 1 және 2-қабаттар биіктігі еденнен потолокқа дейін 3,90 м, астыңғы қабаты биіктігі 2,85 м (оның жер деңгейінен жоғары жағы 1,25 м, жер деңгейінен төменгі жағы 1,60 м).

Ғимараттың салмақ қабылдайтын конструкциясы, яғни салмақ қабылдаушы қабырғалары күйген қызыл кірпіштен қаланып тұрғызылған, қабырғалар қалыңдығы 950 мм (3 кірпіш), цоколь қабаты қабырғасы қалыңдығы 1150 мм болып келеді.

Ғимарат тұрғызылғаннан бастап бүгінгі кезге дейін, яғни бір жарым ғасырға жуық уақыт үздіксіз пайдалануда, бірақ кешенді түрде ғылыми зерттелінген күрделі жөндеу мен қайта қалпына келтіру жұмыстары кешегі күнге дейін жүргізілмеген.

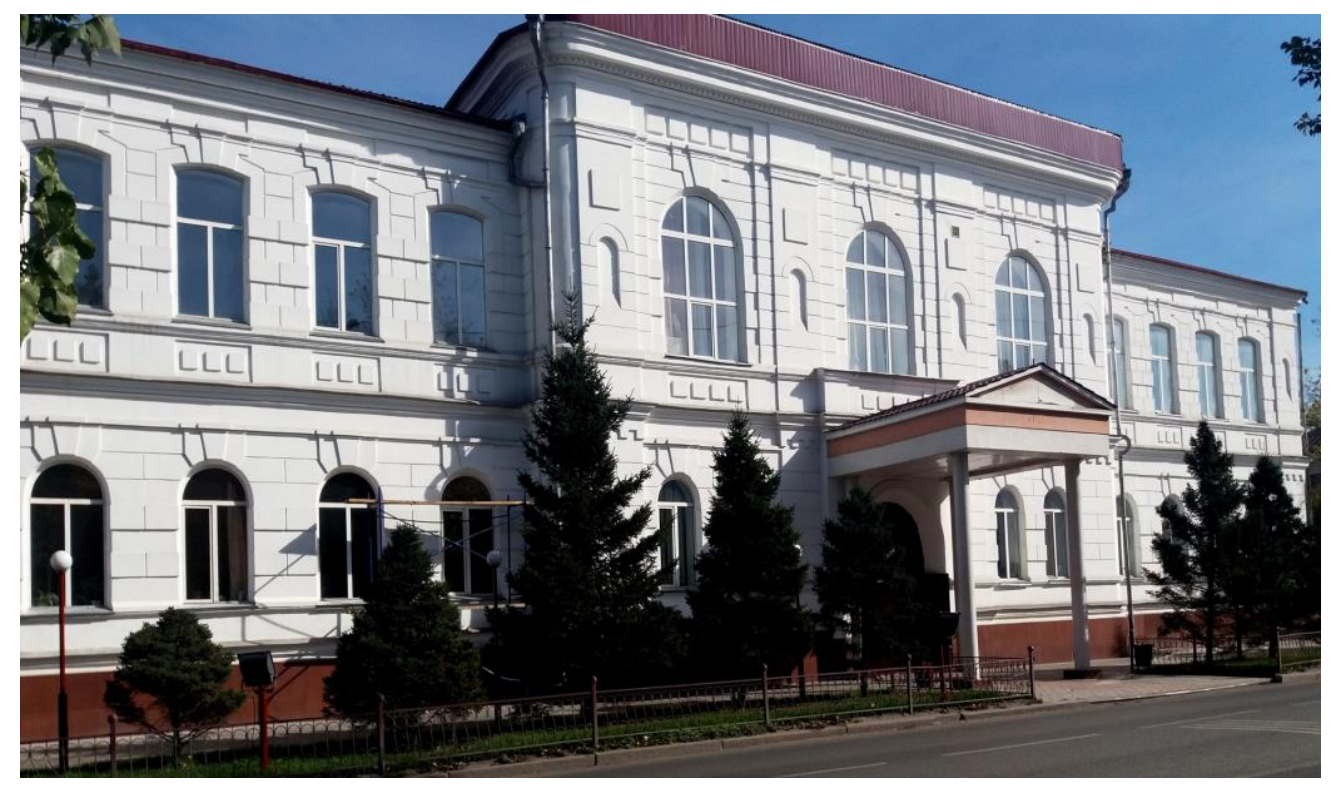

2-сурет - Қазақ инновациялық гуманитарлық-заң университеті ғимаратының қайта қалпына келтіргеннен кейінгі көрінісі 
Қалпына келтіру дегеніміз аз уақытта біте салатын оңай шаруа емес, сондықтан бұл жерде ғылыми-зерттеу жұмысы мен қайта қалпына келтіру қатар жүріп отырады. Өйткені қайта қалпына келтіру яғни тарихи нысандарды жаңғырту кезінде, әр-түрлі қиындықтағы басқа да қосымша жұмыстар жамала береді. Көп жұмыс қолмен, зергерлік дәлдікпен, үлкен шыдамдылықпен істеледі және кәсіби шеберлікті қажет етеді (2-сурет) $[1,3]$.

Нәтижелер және талқылау. Бүгінгі таңда университет басшылығының қолдауымен аталмыш ғимаратқа күрделі жөндеу мен қайта қалпына келтіру жұмыстары дер кезінде сәтті жүргізіліп бітті. Мұндай өте жауапты жұмысқа кіріспестер бұрын, бізге көптеген мәселелерді кезең-кезеңімен, жүйелі түрде шешуге тура келді. Атап айтатын болсақ:

- ғимаратқа жалпы кешенді түрде тарихи-сәулеттік зерттеулер жүргізілді;

- мұрағаттар мен басқа да бүгінгі кезге дейін сақталынып қалған түрлі дереккөздерге шолу жасалынды;

- ғимараттың іргетасынан бастап, цоколь қабатының және салмақ қабылдаушы қабырғаларының жарамдылық деңгейі сарапталынып нәтижесінде оң қорытынды жасалынды;

- ғимараттың (балка, стропила, обрещетка тәріздес) жабын конструкцияларының ары қарай тозып жарамсыз жағдайға жетуінің (ағаш балкалар мен стропилалардың ылғалдан шіріп кетуін, тым қатты кеуіп кетуін) алдын алу мақсатында кезең-кезеңімен бірнеше қалпына келтіру шараларын жүргізу қажеттілігі анықталды;

- ғимараттың негізгі құрылымдық материалы болып табылатын кірпіштердің сапасына сынақтар жүргізіліп, оның сыртқы түрлі табиғи әсерлерге деформацияға ұшырау дәрежесі анықталынып оң қорытынды жасалынды (3-сурет);

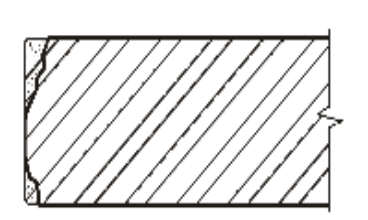

1-кезең
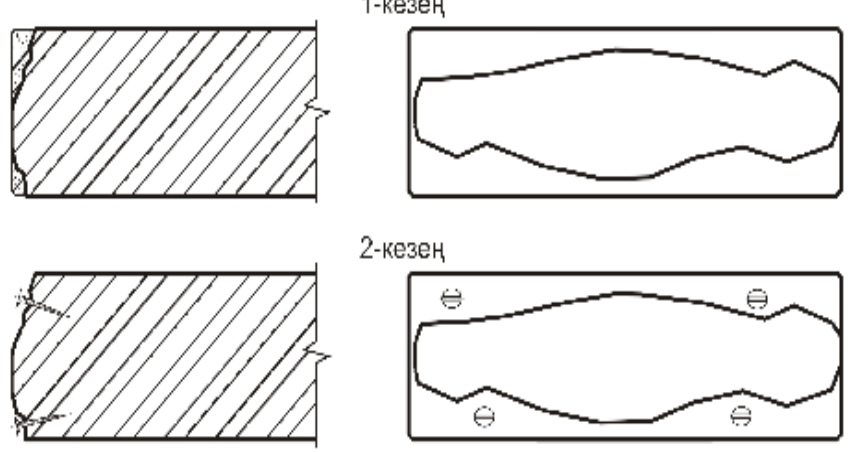

2-кезең
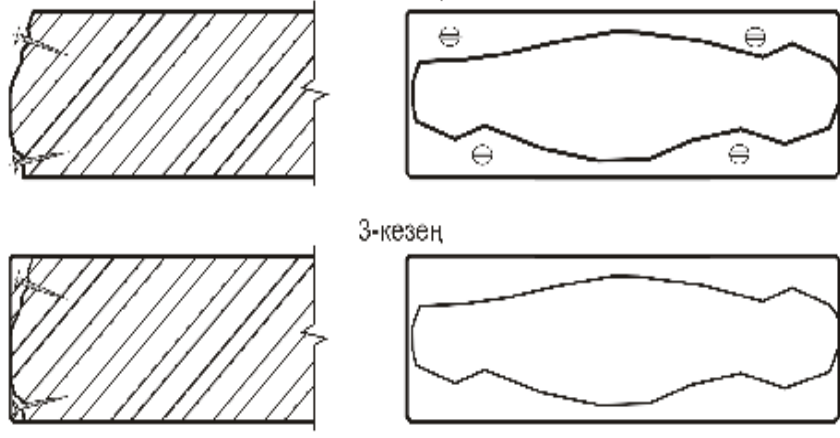

3-кезең

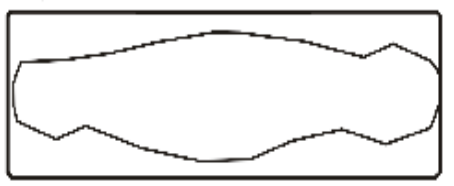

4-кезең
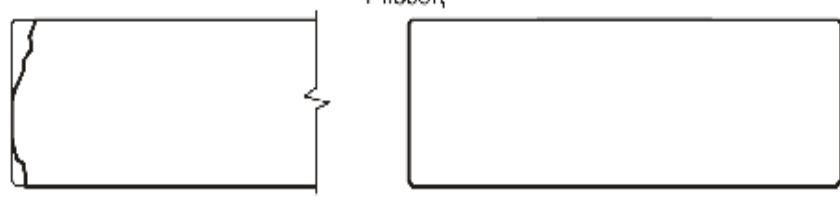

3-сурет - Ғимарат кірпіштерінің сыртқы түрлі табиғи әсерлерге деформацияға ұшыраған бөліктерін қалпына келтіру әдістері 
- ғимараттың бүгінгі кездегі сыртқы сыбақ қабаттарының жарамдылық деңгейіне сараптамалар жүргізілді;

- нысанға нақты зерттеулер жүргізу нәтижесінде қасбет жақ сылақтары мен бояулар қабатының сыртқы беті біршама түрлі сыртқы табиғи әсерлер мен ұзақ уақыт пайдаланудың нәтижесінде түрлі деңгейде зардап шеккені (үгітілгені, жарылғаны) анықталды;

- нәтижесінде жарамсыз деп табылған сыртқы сыбақ қабаттары жүйелі түрде бұзылып (демонтаж) жасалынып оларды жаңа сыбақтармен алмастыру жұмыстары жүргізіліп жатыр (4,5-суреттер);

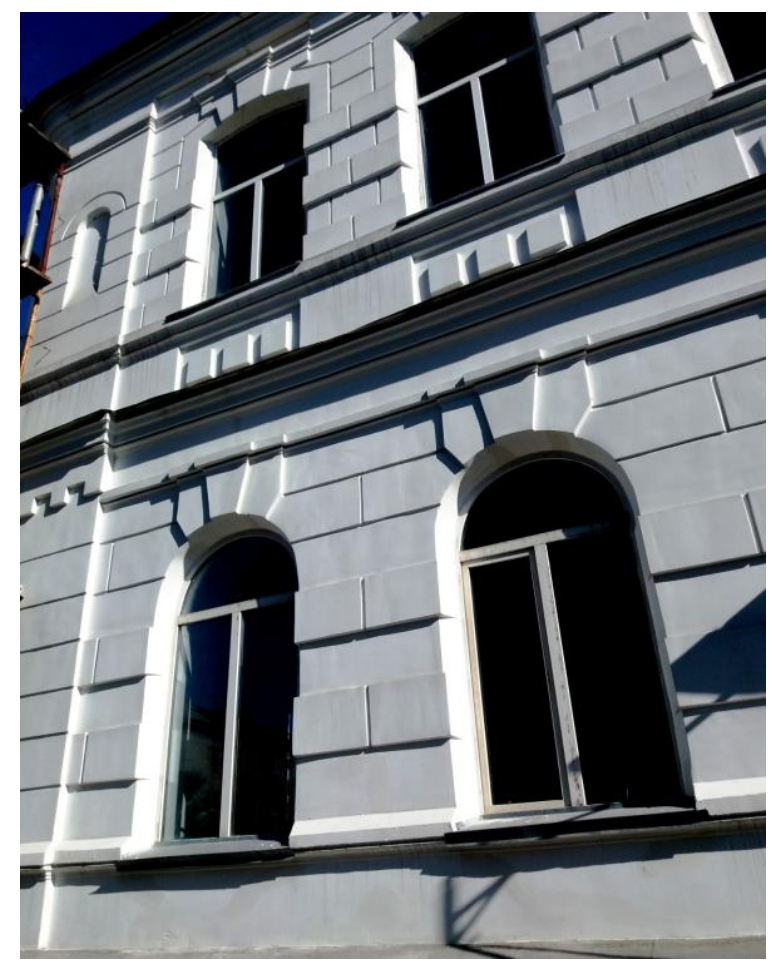

4-сурет - Қазақ инновациялық гуманитарлық-заң университеті ғимаратының қайта қалпына келтіргеннен кейінгі көрінісі (фрагмент)

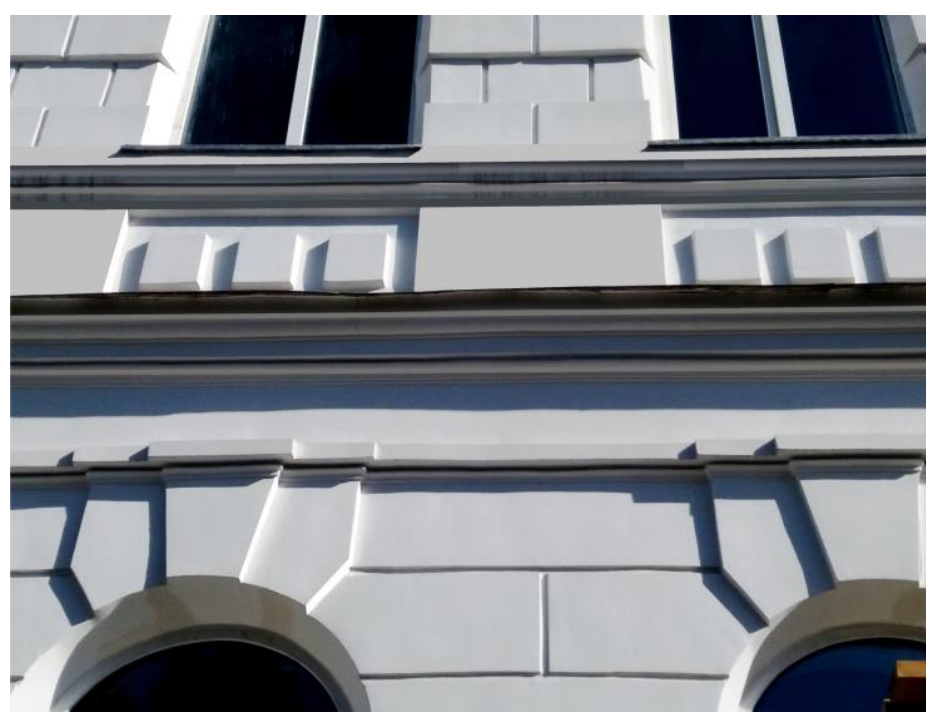

5-сурет. Қазақ инновациялық гуманитарлық-заң университеті ғимаратының қайта қалпына келтіргеннен кейінгі көрінісі (фрагмент) 
- ғимаратты қайта қалпына келтіру барысында оның қасбетінің көркемдік-стильдік ерекшеліктерін сақтап қалу мақсатында, бұрынғы сәулеттік элементтердің негізінде түрлі пішіндерден тұратын қалыптар дайындалып пайдалануда (6-сурет).

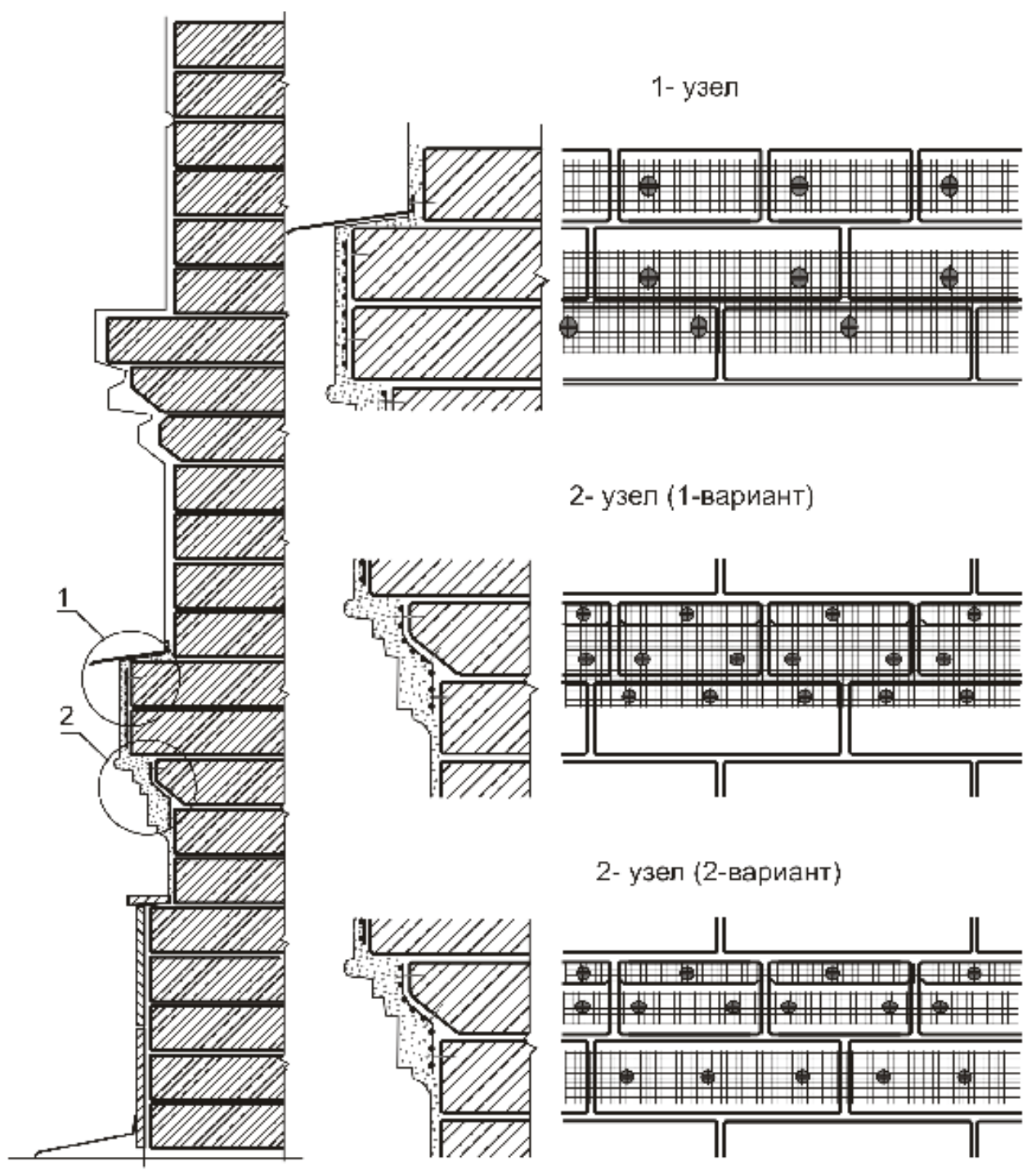

6-сурет - Ғимарат қасбетінің көркемдік-стильдік ерекшеліктері мен сыртқы сәулеттік элементтерін сақтап қалу мақсатында жүргізілген шаралар

Осы тарихи-сәулеттік құндылықты көздің қарашығындай жақсы қалыпында сақтап, қолда бар алтынның қадірін түсініп, оны бүгінгі күнге дейін жеткізген университет басшылығының да еңбегі зор. Себебі бұл жай ғана бір ғимаратқа жөндеу жұмысын жүргізу емес, бұл үлкен жанашырлықпен болашақ ұрпақтың, қала берді тарихтың алдындағы зор жауапкершілікті сезіну, және соның қайтарымын жасау деп түсінеміз [1,5].

Жұмыс барысында университет әкімшілігі оның маңыздылығын жете түсініп, үлкен жауапкершілікпен қарап, кез келген көмекті, оның ішінде қаржылай көмекті дер кезінде қамтамасыз етіп отырды. 
Алдағы таңдарда ғимараттың сыртқы қайта жаңғырту жұмыстарын жалғастырумен қатар, оның интерьерлік безендіруін қайта қалпына келтіру, шатыр қабатының ағаш құрылымдарының сапасын арттыру, сонымен қатар ішкі табиғи ауа тазарту және жылыту жүйелерін зерттеп, мүмкін болған жағдайда оны іске қосу жоспарланып отыр. Бұл дегеніміз ғимараттың сыртқы сәулеттік-көркемдік шешімімен шектеліп қана қалмай, сонымен бірге оның алғашқы жұмыс істеу қалпын қайта жаңғыртуға талпыныс жасау деген сөз [2].

Бүгінгі күнге дейін орындалған ғылыми-зерттеу және тәжірибелік жұмыстардың және алдағы орындалатын жұмыс нәтижелерінің негізінде сандық каталогтар мен монографиялық жұмыстар жазу жоспарланып отыр.

Мұндай игі бастама Семей қаласында алғаш рет осы университетке тиесілі ғимараттан басталып отырғанын айтып кетуіміз керек. Осындай шаралар бүкіл қала деңгейінде өзінің жалғасын тапса деген үміттеміз.

XVIII-XIX-ғасырлық сәулеттік-тарихи інжу-маржандарына бай Семей қаласын бүкіл әлемдік деңгейдегі сәулеттік-тарихи құндылығы бар Түркістан, Тараз, Сайрам сияқты қалалардың қатарына қосыу. Осылайша әлемдік туризмі дамыған қалалардың қатарына тарту. Біз ойлаймаз мұндай сәулеттік-тарихи қазыналарды қалпына келтіріп сақтау, әкімдіктен бастап осындай тарихиғимататтарды иемденіп отырған азаматтардың алдындағы қазіргі кездегі кезек күттірмейтін өзекті мәселелерінің бірі болуға тиіс деп [3].

Қазір Семей қаласында көптеген тарихи құндылығы бар сәулеттік ескерткіштердің жағдайы сын көтермейді. Бір ғана мысал бұрынғы Семей малдәрігерлік институттың тағдырын айтсақ та жеткілікті! Бұл ғимарат тек қана Қазақстанда емес, сонымен қатар, Ресейде де өзінің аналогы жоқ бірегей, еш жерде қайталанбаған сәулеттік өте құнды нысан болып табылады [4,5].

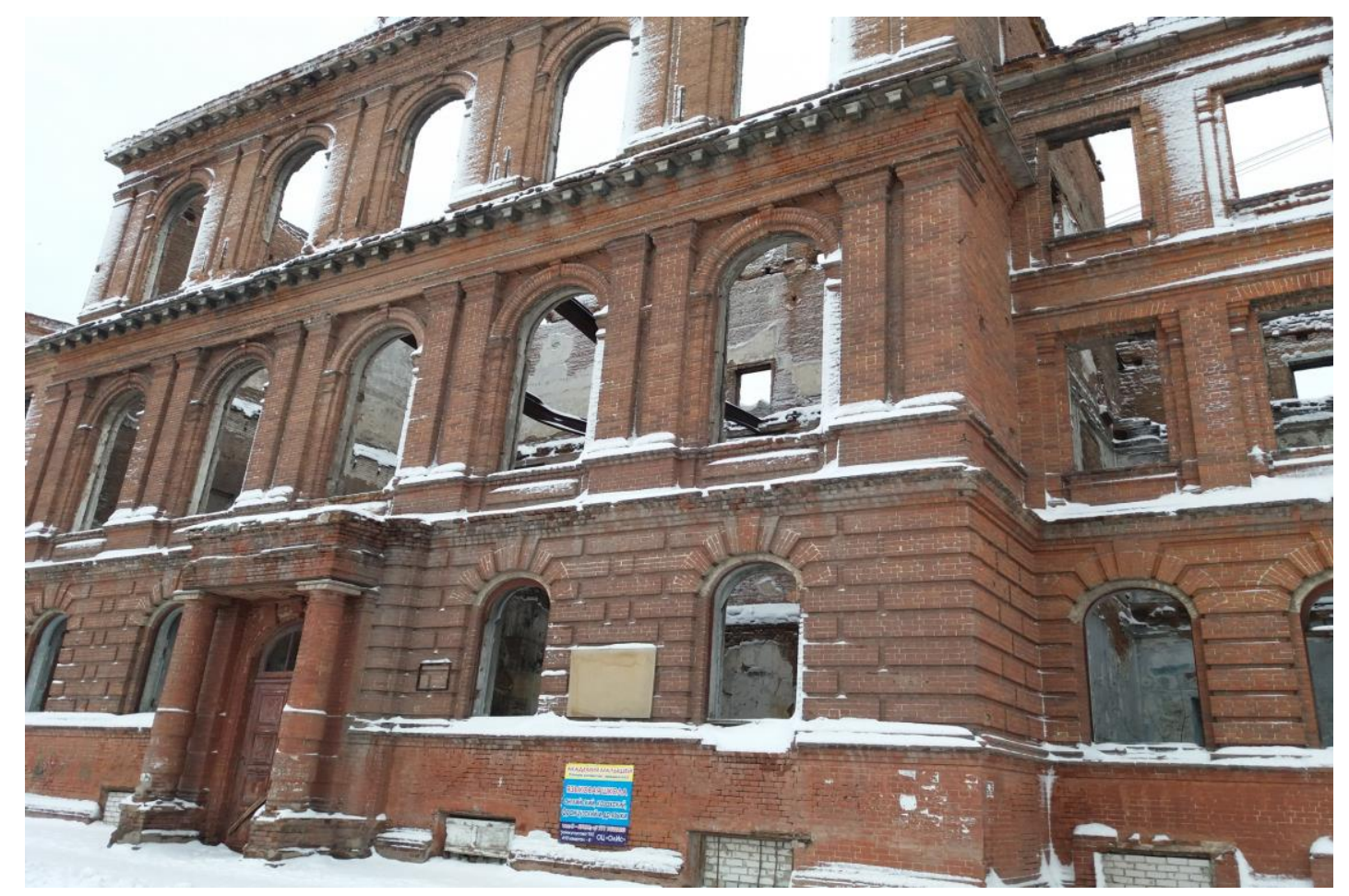

7-сурет - Бұрынғы Семей малдәрігерлік институты ғимаратының қазіргі көрінісі 
Революцияға дейінгі соғылған ғимарат (сол кездегі қыздар гимназиясы), 1917 жылы 10 желтоқсанда кешкісін акт залында бірінші рет, 69 жылдан кейін, 1986 жылы 9-желтоқсанда екінші рет өртенген, содан бері табаны күректей 35 жыл өтіпті, қазіргі кезде қайран ғимарат қабырғасы ырсиып, жылдардың шежіресіндей, «Қашанға дейін шыдар екенмін» дегендей қасқайып немесе қалқиып міз бақпай бөркін алып ойланып тұр, мұндай көрініске жанашырлықпен қарамай өту тіпті де мүмкін емес (7-сурет). Ғимараттың жыл санап түрлі деформацияға ұшырап жатқандығы, тағы да бір рухани құндылық «Көз алдымызда ғайып болады ау» деген көңілге күдік ұялатады!

\section{Корытынды}

Мақаланың соңында Рухы биік ел, тарихын құрметтеп, құндылықтарын бағалай білген, сондықтан да мұндай елдің болашағы айқын, мақсаты нық екендігін естен шығармайық ағайындар, дегім келеді!

\section{Әдебиеттер:}

1. Арынов К.К. Архитектура зданий ремесленных ичентров: монография. - Астана: ИП «Дана» издательство, 2018. - 271 с.: ил.

2. Казахская ССР: краткая энцииклопедия / Гл. ред. Р. Н. Нургалиев. - Алма-Ата: Гл. ред. Казахской советской энииклопедии, 1991. - Т. 4: Язык. Литература. Фольклор. Искусство. Архитектура. - С. 381. - 31300 экз.

3. Шәймерденов К. Тарихи ескерткіштер рухани ққазына байлықтары. - Шымкент, 1981.

4. Тасмаванбетов И. Сәулет өнерінің асыл туындысы. - Алматы, 2005.

5. Тоқтабай А. Ескеркіштер - ел тарихы: тарихи ескерткіштерге рестобрация жасау мәселелері // Қазақ ддебиеті, 2003 мамыр.

\section{References:}

1. Arynov K. K. Architecture of buildings of craft centers: monograph. - Astana: IP «Dana» publishing house, 2018. - 271 p.: ill.

2. Kazakh SSR: a short encyclopedia / Ch. ed. R.N. Nurgaliev. - Alma-Ata: Ch. ed. Kazakh Soviet Encyclopedia, 1991. - Vol. 4: Language. Literature. Folklore. Art. Architecture. - P. 381. 31,300 copies.

3. Shaimerdenov K. historical monuments spiritual treasures. - Shymkent, 1981.

4. Tasmaganbetov I. A noble work of Architecture. - Almaty, 2005.

5. Toktabay A. Monuments - History of the country: problems of restoration of historical monuments // Kazakh literature, May 2003.

\section{К.К. Арынов *}

Евразийский национальный университет им. Л.Н. Гумилева, Нур-Султан, Казахстан

\section{Информация об авторе:}

Арынов Калдыбай Канаевич - доктор архитектуры, профессор Евразийского национального университета им. Л.Н. Гумилёва, Нур-Султан, Казахстан https://orcid.org/0000-0003-0799-8574, e-mail: kalan1960@mail.ru 


\section{АРХИТЕКТУРНО-ИСТОРИЧЕСКАЯ ЦЕННОСТЬ - ДОСТОЯНИЕ НАРОДА}

Аннотация. $B$ статье затрагиваются результать поэтапной реставрационной работы архитектурно-исторических памятников учебных зданий Казахского гуманитарноюридического иноваџионного университета расположенного по адресу город Семей, улица Абая, 94 и текущие состояние других иеенных исторических памятников имеющие духовные значения перед будущих поколений страны.

Ключевые слова: памятники, имеющие архитектурно-историческю иенность, реставрация, капитальный ремонт, фасад здания, построенного в стиле русского классицизма.

\section{K.K. Arynov*}

Eurasian National University. L.N. Gumilyova, Nur-Sultan, Kazakhstan

\section{Information about the author:}

Arynov Kaldybai Kanaevich - Doctor of Architecture, Professor of the Eurasian National University named after I. L.N. Gumilyov, Nur-Sultan, Kazakhstan

https://orcid.org/0000-0003-0799-8574, email: kalan1960@mail.ru

\section{ARCHITECTURAL AND HISTORICAL VALUE - THE PROPERTY OF THE PEOPLE}

Annotation. The article touches upon the results of the phased restoration work of architectural and historical monuments of educational buildings of the Kazakh Humanitarian and Legal Innovation University located at the address Semey city, Abai Street, 94 and the current state of other valuable historical monuments that have spiritual significance for future generations of the country.

Keywords: monuments of architectural and historical value, restoration, overhaul, facade, building built in the style of Russian classicism. 